\title{
Betydelsen av brobyggare. Det etablerade civilsamhället och förortsrörelsen
}

\author{
Lisa Kings
}

SAMMANDRAG: Lisa Kings artikel studerar individer som fungerat som så kallade brobyggare mellan äldre civilsamhällesorganisationer och en ny förortsrörelse i Sverige. Materialet utgörs primärt av intervjuer med professionellt verksamma i tre etablerade civilsamhällesorganisationer. Analysen visar att brobyggarnas roll och position har använts för att stödja förortsrörelsens uppstart, men att brobyggarnas kamp i förlängningen handlat om att förändra och (re)vitalisera den egna organisationen. I ljuset av detta illustrerar behovet av brobyggare den distans och asymmetriska relation som finns mellan civilsamhällets centrum och periferi. Avslutningsvis diskuteras det om betydelsen av brobyggare kan ses som en övergripande trend som bottnar i ett alltmer uppdelat civilsamhälle i Sverige.

NYCKELORD: brobyggare; civilsamhälle; sociala rörelser; förortsrörelsen; strukturella hål; främlingen.

PUBLICERINGSHISTORIK: Originalpublicering.

LISA KINGS är lektor i socialt arbete vid Södertörns högskola.

E-POSTADREss: lisa.kings@sh.se

\section{FÖRSLAG PÅ KÄLLANGIVELSE:}

Kings, Lisa (20I8) "Betydelsen av brobyggare. Det etablerade civilsamhället och förortsrörelsen", i Platskamp, specialnummer av Arkiv. Tidskrift för sambällsanalys, nr 9, s. 77-IO2.

DOI: https://doi.org/IO.I3068/2000-62I7.9.3

(C) Lisa Kings/Arkiv förlag \& tidskrift 2018 (publicerad 28 maj 20I8)

Artikeln distribueras enligt en upphovsrättslicens från Creative Commons:

Erkännande-Ickekommersiell-IngaBearbetningar 3.0 Unported, som medger fri ickekommersiell användning och spridning i oförändrat skick så länge källan anges. 
Arkiv. Tidskrift för samhällsanalys är en sakkunniggranskad vetenskaplig tidskrift för samhällsvetenskap och historia. Samtliga artiklar publiceras fritt tillgängliga på:

$$
\text { www.tidskriftenarkiv.se }
$$

Beständig länk, DOI: https://doi.org/IO.I3068/2000-62I7

Den här artikeln finns tillgänglig i följande format:

PDF: via beständig länk, DOI: https://doi.org/IO.I3068/2000-62I7.9.3

TRYCK: ingår i bokutgåva av numret, ISBN: 978 9I 79243159

Grafisk utformning och sidnumrering är identisk i pdf och tryck.

Samtliga artiklar i nr 9 (2018), Platskamp, nås via beständig länk, DOI: https://doi.org/I0.I3068/2000-6217.9

Redaktion för nUmret: Magnus Dahlstedt, Lisa Kings \& Nazem Tahvilzadeh

Arkiv. Tidskrift för sambällsanalys

ISSN: 2000-62I7 (för elektronisk resurs)

ISSN: 2000-6225 (för tryckta nummer)

ges ut av

Stiftelsen Arkiv för främjande och spridning av samhällsvetenskaplig och historisk forskning

\author{
genom \\ Arkiv förlag \& tidskrift \\ Box 1559 \\ SE-22I OI Lund \\ BESÖK: L Gråbrödersg 3 c, ipg \\ TEL: 046-I3 3920
}

ARKIV FÖRLAG: arkiv@arkiv.nu·www.arkiv.nu

TIDSKRIFTEN ARKIV: red@tidskriftenarkiv.se.www.tidskriftenarkiv.se

ANSVARIg UTGIVARE \& CHEFREDAKTÖR: Sven Hort

AdMinistrativ Redaktör: David Lindberg

Redaktörer: Paavo Bergman, Per Dannefjord, Lisa Kings,

Zhanna Kravchenko, Anna-Maria Sarstrand Marekovic 


\title{
Betydelsen av brobyggare. Det etablerade civilsamhället och förortsrörelsen
}

\author{
LISA KINGS
}

\section{Inledning}

De senaste åren har framväxten av en så kallad förortsrörelse med unga från marginaliserade storstadsområden rönt stor uppmärksamhet. Två av de mest framträdande organisationerna, åtminstone i den mediala debatten, har varit Megafonen i Stockholm och Pantrarna för upprustning av förorten i Göteborg. Andra exempel på organisationer som arbetar eller har arbetat mot samma grupp av människor är bland annat Förorternas riksdag, Förorten i centrum, Gatans röst och ansikte och Förorten mot våld. Dessa organisationer skiljer sig åt när det gäller exempelvis inriktning, grad av professionalisering och vilken typ av resurser som är viktigast för verksamheten. Som namnen på organisationerna antyder finns det - trots de inbördes olikheterna - en gemensam nämnare i idén om att platsen, direkt eller indirekt, är central för organisationernas mobilisering och verksamheter. Förorten, eller bara orten, levd och föreställd, utgör med andra ord den gemensamma grunden eller rörelsens sociala bas. Inom rörelsen har identifikationen av en ny social bas också kombinerats med en mer traditionell organisationsform genom starka band till organisationens medlemmar samt inåtriktad social verksamhet och utåtriktat förändringsarbete (se t.ex. León Rosales \& Ålund 2018 [i detta nummer]; Kings 20I4; Schierup m.fl. 20I4).

I denna text står relationen mellan den framväxande förortsrörelsen och det etablerade civilsamhället i Sverige i fokus. Den övergripande 
utgångspunkten är att det organisatoriska landskapet är centralt både för att förstå hur nya rörelser växer fram (se även Kings 20I4) och, som vi kommer att se, för förståelsen av nya rörelsers inflytande i samhället i stort. Mot denna bakgrund är syftet koncentrerat till en "individualiserad" aspekt av relationen mellan det "nya" och "etablerade" civilsamhället, nämligen det man kan benämna "brobyggare". Därmed avses den position som överbryggar sociala gränser och förenar två eller flera tidigare åtskilda grupper (Stovel \& Shaw 20I2; McAdam m.fl. 200I; jfr Simmel 198I [1908]). I det här fallet handlar det om hur individer i etablerade organisationer fungerar som dubbelriktad kommunikationslänk mellan de äldre civilsamhällesorganisationerna och den nya förortsrörelsens organisationer. Frågeställningarna som vägleder denna studie lyder som följer: vilka är de som identifieras som brobyggare i detta sammanhang, hur blev de brobyggare och på vilket sätt arbetar de med att överbrygga olika typer av gränser?

Analysen är baserad på intervjuer med brobyggare från tre olika civilsamhällesorganisationer. Dessa individer skiljer sig från de unga aktivisterna när det gäller ålder, status och position. Vidare kan de inte heller ses som en äldre enhetlig grupp vilken fungerar som en förlängd representant för den unga rörelsen. De aktuella brobyggarna utgör en blandad grupp, men delar en gemensam analys där de vill arbeta för förändring i samhället i stort och inom de organisationer där de verkar.

Studien visar att brobyggarnas roll och position har använts för att stödja förortsrörelsens uppstart genom att frigöra kapital, stödja och skydda, men den visar också hur brobyggarnas kamp i förlängningen handlar om att förändra den egna organisationen. Den lärprocess och det nätverk som utvecklats mellan å ena sidan enskilda individer inom det etablerade civilsamhället och å den andra yngre aktivister visar hur förortsrörelsens grundläggande idéer och målsättningar används för att underbygga försök att vitalisera etablerade civilsamhällesorganisationer i Sverige. Resultatet av studien synliggör i förlängningen också den distans och asymmetriska relation som finns mellan förortens organisationer och de etablerade civilsamhällesorganisationerna. Avslutningsvis diskuteras huruvida betydelsen av brobyggare, i detta fall mellan etablerade civil-

I. En översättning av den engelska termen broker. 
samhällesorganisationer och en framväxande förortsrörelse, illustrerar en mer övergripande utveckling mot ett alltmer uppdelat civilsamhälle.

\section{Bakgrund}

En social rörelse binder samman sociala processer med individens och kollektivets reaktioner på desamma (jfr Olofsson 1995). Sociala rörelser innefattar på så sätt aktörer som delar vissa grundläggande föreställningar om omvärlden, känner solidaritet med varandra och agerar för att förändra eller bevara samhället (se exempelvis Tarrow 1994). Inom ramen för en social rörelse finns det specifika sociala rörelseorganisationer som kan arbeta på olika sätt men som delar samma övergripande mål och utgör viktiga delar för rörelserna som helhet (Meyer \& Tarrow 1998). Förortsrörelsens olika organisationer har mobiliserats kring platskamp - eller kamp om plats - vilket ska ses i förhållande till den samtida samhällsutvecklingen mot ökad ojämlikhet, segregation och rasism (se exempelvis Kings m.fl. 20I6; Sernhede 20I4), något som i den allmänna debatten diskuteras i form av segregation och skapandet av gränser som följer klassmässiga och etniska skiljelinjer. Utvecklingen blir tydlig när man beaktar hur bemedlade grupper stänger in sig själva i områden bakom synliga eller osynliga murar, medan mindre bemedlade grupper stängs ute och koncentreras till lågstatusområden som medför sämre tillgång till lokal välfärd och social infrastruktur (för en svensk översikt, se Urban 20I8). Men denna utveckling mot alltmer delade städer är långt ifrån unik för den svenska kontexten utan ses som en konsekvens av en global trend av nyliberal urbanism som också skapar särskilda förutsättningar för möjligheter till organisering och motstånd (se exempelvis Mayer m.fl. 20I6; Thörn 20I3). Detta gör att olika typer av protester, alltifrån våldsamma uppror till mindre högljudda lokalföreningar, med ett mer eller mindre uttalat urbant perspektiv kommit att intressera forskare världen över (se exempelvis Mayer m.fl. 20ı6; Nicholls \& Uitermark 2017).

I Sverige har Ulf Stahre (2007) under många år studerat urbana sociala rörelser. I en periodisering av urbana sociala rörelser i Stockholm lyfter han fram skillnaderna mellan rörelser verksamma under i960-talet 
fram till $1990-$ talet och de urbana rörelser som varit aktiva från millennieskiftet och framåt. I denna uppdelning menar han att det skett en förskjutning från så kallade stadsmiljörörelser som var primärt reaktiva och inriktade på fysiska aspekter i staden till rörelser som är i opposition och kritiska mot den nyliberala stadspolitiken som helhet (Stahre 2007). Förortsrörelsen kan utan större problem placeras in i den senare kategorin eftersom rörelsen lyfter frågan om stadens politik som helhet. Det som dock kan skilja ut förortsrörelsen är dess betoning på gräsrotsmobilisering på de platser som görs till den nyliberala stadens baksida - i detta svenska fall de så kallade miljonprogramområdena i städernas utkanter. Rörelsens organisationer har till viss del också arbetat mer traditionellt med att stärka lokalsamhället genom medvetandegörande och frigörelse samt olika typer av kompenserande serviceinsatser och reaktiva protestaktioner, vilket för övrigt var vår utgångspunkt när vi i en tidigare studie definierade dem som en urban rättviserörelse (Schierup m.fl. 20I4). Vidare verkar inte heller de samtida urbana protesterna och organisationerna från väst vara en särskilt framträdande inspirationskälla för förortsrörelsen. I stället går det att spåra inspiration, ideologi och strategier till kamper i andra sammanhang och tider. Den Stockholmsbaserade organisationen Megafonen har exempelvis använt slagorden "en enad förort kan inte besegras", vilket är en referens till den antiimperialistiska kampen i Latinamerika. Ytterligare en internationell och historisk referens, här i form av den svarta medborgarrättsrörelsen, finner vi i namnet till organisationen Pantrarna för upprusning av förorten som är lokaliserad till Göteborg (Schierup m.fl. 20I4).

Utan att förneka den globala sammankopplingen av olika rörelser i dag eller dess inflytande på förortsrörelsen är det nationella organisatoriska landskapet fortfarande av central betydelse (Wijkström m.fl. 20I7; Ahrne \& Papakostas 20I4). I denna text är det särskilt civilsamhällets organisering i marginaliserade förortsområden och i förlängningen civilsamhällets förändringar i Sverige i stort som står i blickfånget och utgör den bakgrund mot vilken betydelsen av brobyggare mellan det etablerade civilsamhället och förortsrörelsen ska förstås. 


\section{Det civilsamhälleliga landskapet i Sverige: omförhandlingar och splittring}

Förortsrörelsen framträder $\mathrm{i}$ en tid då det etablerade civilsamhället i Sverige befinner sig i omvandling (Wijkström 20I2). Både i den offentliga debatten och inom de traditionella organisationerna förs en diskussion om det etablerade civilsamhällets stagnation och behovet av förnyelse. Bakgrunden till detta är att man kunnat se hur engagemanget i frivilliga föreningar minskat sedan 1990-talet både gällande medlemskap, antalet aktiva medlemmar och förtroendevalda (Vogel m.fl. 2003; Lundström \& Wijkström 1997). Det handlar här om minskade medlemsantal och ökad distans mellan passiva och aktiva medlemmar, men också om att särskilt vissa grupper - till exempel unga män och invandrare - är relativt oorganiserade i det etablerade civilsamhället (Amnå 2007). I linje med denna utveckling har man inom förortsrörelsens organisationer ifrågasatt det etablerade civilsamhällets brist på lokal förankring i, och representativitet från, dessa områden (Kings 20I4). Visserligen existerar ett aktivt föreningsliv i marginaliserade bostadsområden, men detta består till stor del av små lokalföreningar som ofta saknar organisatorisk struktur bortom närområdet. Till skillnad från den så kallade förortsrörelsen gör detta att lokalföreningarnas autonomi och möjlighet till politisk påverkan är begränsade (Kings 20II).

Omvandlingen av det etablerade civilsamhället handlar emellertid om mer än förlusten av medlemmar och förmågan att nå vissa platser och grupper av människor. Det handlar i förlängningen om hur relationen mellan civilsamhället och staten kommer att organiseras i Sverige. Civilsamhället i Sverige har länge betraktats som komplement till staten, där föreningslivet agerar fritt men är nära förbundet med staten (Heckscher 1946; Rothstein 1992). Frågan har diskuterats i termer av en särskild folkrörelsetradition. Begreppet "folkrörelse" är behäftat med den breda folkliga mobilisering som kännetecknar den svenska historien (Olofsson 1995). Namnet kommer från att rörelserna - i motsats till överklassens politiska praktik - organiserar människor underifrån, oberoende av samhällsposition eller eventuell expertis. Folkrörelsernas dominanta position i det svenska civilsamhället har en smula raljerande 
benämnts som "den svenska folkrörelsemarinaden" (Wijkström 20II). Därmed avses att organisationer i Sverige oavsett bakgrund, form och innehåll tidigare "tvingats" anpassa sig till folkrörelsernas särskilda struktur, med exempelvis formella medlemskap, geografisk uppdelning mellan nationell, regional och lokal nivå, demokratiska beslutsformer samt en konsensusinriktad relation till staten. Denna bakgrund är gemensam för de organisationer som de aktuella brobyggarna arbetar för, oavsett om de kan kategoriseras som traditionell folkrörelse eller inte.

Omförhandlingar inom det etablerade civilsamhället har bland annat enligt Wijkström (20I2) lett till en "omvänd samtalsordning" där civilsamhälleliga organisationer, som historiskt haft en idébärande, röstbärande eller åtminstone påtryckande funktion, alltmer kommit att hamna i en utförarroll. Samtidigt har de befintliga systemen för att transformera medel till civilsamhället förskjutits "från bidrag till ersättning", så att det offentliga kommit att förvänta sig att civilsamhällets organisationer ska ta på sig särskilda uppdrag eller driva verksamheter på entreprenad. Det svenska civilsamhällets tidigare så starka relation till staten, och då särskilt genom sin delaktighet i att utforma politiken, har förskjutits mot ett närmande till marknaden och dess premisser särskilt när det gäller utövare av samhällstjänster (Wijkström 20I2). Men det är inte bara civilsamhällets verksamheter och förutsättningar som förändras. Även civilsamhällesorganisationerna som sådana har rationaliserats (Papakostas 20II) genom att utvecklas mot ökad distans mellan medlemmar och ledare. Detta diskuteras också som en ökad professionalisering i civilsamhällets organisationer, där ett fătal avlönade driver organisationen medan medlemmarna i större utsträckning köper tjänster eller skänker månatliga bidrag snarare än att vara aktiva i och identifiera sig med en organisation. Sammantaget illustrerar dessa tendenser hur gränser mellan civilsamhälle, stat och näringsliv förflyttas. Därmed har den relation mellan stat och civilsamhälle som ansetts vara relativt unik i världen om inte för Sverige så i alla fall för Norden - kommit att omförhandlas i en riktning som alltmer liknar klassiska liberala välfärdsstater som USA, England och Kanada.

Mot denna bakgrund är det kanske inte så konstigt att det etablerade civilsamhället inte, oavsett om det är på grund av ovilja eller oför- 
måga, lyckats möta upp de lokala behov och de protester och krav på förändring som finns i stadens marginaliserade områden. Det är i skärningspunkten mellan den idealtypiska folkrörelsens dominerande marinad och framväxten av potentiellt nytt civilsamhälleligt landskap som förortsrörelsen och, i denna text, de individuella brobyggarna och deras hemorganisationer verkar.

\section{Urval och material}

Denna studie är genomförd inom ramen för forskningsprojektet Urbana rättviserörelser, finansierat av Formas (projektnummer 250-20I3-I547). Det faktum att fokus inriktats på individuella positioner snarare än relationen mellan olika typer av organisationer är i denna text empiriskt motiverat. Under tidigare intervjuer med aktivister inom förortsrörelsen blev det tydligt att det framför allt handlade om kontakter med och förtroende för individer inom etablerade civilsamhällesorganisationer snarare än om organisationer som helhet. Kartläggningen och identifieringen av så kallade brobyggare har med andra ord gjorts med hjälp av aktivister inom förortsrörelsen. Mer konkret har aktivister under intervjuer fått direkta frågor om samarbete och kontakt med personer och andra organisationer från det etablerade civilsamhället. Sammanlagt identifierades sex personer tillhörande det etablerade civilsamhället som haft en viktig roll under rörelsers uppstart i Stockholm, och då särskilt organisationen Megafonens tillblivelse i nordvästra Stockholm. De utgörs av en kvinna och fem män födda mellan år 1949 och 1980. Samtliga personer som identifierats genom kartläggningen har intervjuats under åren 20I4-20I7. Intervjuerna omfattar cirka 90-I40 minuter och har spelats in och transkriberats. Intervjuerna har kompletterats med informella samtal, mötesdeltagande och organisationsdokumentation.

Dessa personer är eller har varit tjänstepersoner på tre olika etablerade och rikstäckande civilsamhällesorganisationer. Två av dessa organisationer kan karaktäriseras som traditionella svenska folkrörelser. Den tredje är en medlemsorganisation i Sverige men också en internationell organisation med en över hundraårig historia. Historiskt startade den som en välgörenhets- och biståndsorganisation men har utvecklats 
mot att också driva rättighetsfrågor. Av förklarliga skäl, särskilt i form av uppenbara skillnader i ålder, status och position, delar brobyggarna inte de unga aktivisternas erfarenheter av i dag. Även om vissa av dem har arbetarklassbakgrund, egen erfarenhet av rasifiering eller av att växa upp i dåtidens urbana periferi skiljer sig deras erfarenheter och samtida positioner från de yngre aktivisternas. De kan därför inte förstås som en förlängd representant för den unga rörelsen. Noteras bör därför att de brobyggare som står i fokus för denna studie inte omfattar de unga aktivister från förortsrörelsen som med tiden fått alltmer framskjutna positioner i olika typer av organisationer, både inom den statliga och civilsamhälleliga sfären. I stället är det just betydelsen av etablerade individer inom det traditionella civilsamhället, och då särskilt i relation till förortsrörelsens uppstart, som står i fokus i denna text.

\section{Brobyggare och strukturella hål}

Brobyggare är ett klassiskt fenomen inom samhällsvetenskapen även om det ibland kan gå under andra benämningar som medlare, översättare eller facilitator. Inom antropologin och dess nära och empiriskt känsliga studier är det kanske särskilt den kulturella medlaren i utvecklingsstudier man tänker på (Lindqvist 20I5). Brobyggare har också en särskild plats i studier, särskilt sociologiska sådana, av organisationsutveckling, entreprenörskap och innovation (Burt 2004). Inom fältet sociala rörelser har brobyggarnas centrala betydelse bland annat diskuteras i undersökningar av temporära allianser mellan olika typer av vanligtvis etablerade och nya rörelser (Polanska 20I5; Rose 2000). Oavsett forskningsfält innebär en grundläggande definition av en brobyggare att det är en aktör som fungerar som "spindeln i nätet” mellan två eller fler aktörer. Vederbörande har förmågan knyta samman tidigare isolerade, polariserade eller för varandra okända aktörer. Det handlar alltså om att en tredje part för samman aktörer i form av individer eller grupper som inte kände till varandra eller som inte uppfattat att de har något gemensamt. Men det kan också handla om att fungera som en medlare mellan aktörer som tidigare inte haft förtroende för varandra eller som till och med har en historia av öppen osämja (Stovel \& Shaw 20I2). Denna studie tar avstamp i 
teoretiseringen kring brobyggandet inom organisationsförändringar och sociala rörelser i stort. Mer specifikt omfattas de som arbetar på en etablerad civilsamhällesorganisation och har eller har haft en särskild relation till en eller flera individer inom förortsrörelsen, där de fungerat som en länk mellan organisationer som varit åtskilda på grund av en social distans som till viss del även geografisk. Centralt här och vidare i den kommande analysen är att brobyggandet inte behöver vara enkelriktat. Det handlar inte om att en organisation behöver få hjälp eller stöd av en annan, utan brobyggarnas sammanlänkande av tidigare åtskilda organisationer kan ha betydelse för flera parter.

Till följd av brobyggandet ${ }^{2}$ skapas nya flöden av resurser, exempelvis varor, tjänster eller information. Här intar brobyggaren en aktiv roll $\mathrm{i}$ stället för att passivt överföra kunskap, varor eller information från en aktör till en annan. Inom företagsekonomi kan det exempelvis handla om produktinnovation eller lansering av en existerande produkt på en ny marknad och för sociala rörelser kan samarbeten eller koalitioner mellan två olika rörelser i en fråga leda till att en organisation exempelvis går från att arbeta lokalt till att bli rikstäckande (McAdam m.fl. 200I). Walter J. Nicholls och Justus Uitermark (20I7) visar också på brobyggandets betydelse för en radikal pluralistisk aktivistmiljö. Genom att aktivister, nätverk och organisationer inom den latinamerikanska gruppen för invandrares rättigheter i 1970-talets Los Angeles utbytte strategier och idéer, formades under några år en tillåtande miljö som främjande en gemensam kamp för latinamerikaner bosatta i USA. I föreliggande studie handlar det om en mer småskalig form av brobyggande, där enskilda individer i etablerade organisationer vill förändra arbetssätt och fokus inom den egna organisationen samtidigt som de gärna vill stötta och uppmuntra framväxten av förortsrörelsen.

Brobyggarrollen uppfattas vanligen som en kritisk position och en motor för förändring, oavsett om den leder till institutionalisering, radikalisering eller något annat. Men det är också en position som innebär möjligheter till exploatering, personlig vinning, korruption och maktfullkomlighet (Stovel \& Shaw 2012). Denna uppdelning mellan att se brobyggarens maktposition som antingen facilitator eller parasit har dock

2. En översättning av den engelska termen brokerage. 
kritiserats för att vara normativ snarare än empirisk (Olivier de Sardan 2005). Vidare finns det inget som säger att rollerna som facilitator och parasit inte kan sammanfalla eller avlösa varandra över tid, beroende på vilket perspektiv man antar.

\section{Brobyggaren - främlingen som täpper till strukturella hål}

Det som kännetecknar brobyggarna är att de verkar i gränssnittet mellan skilda uppfattningar, erfarenheter och kunskaps- eller värdesystem, i detta fall illustrerade genom organisationer sprungna ur olika epoker och i olika stadier av utveckling, institutionalisering och professionalisering och med skilda typer av medlemsbaser. Här blir förhandling, relationer och representation av vikt när det kommer till att länka samman olika aktörer. En brobyggare måste kunna navigera i olika sammanhang, möta olika typer av grupper och ha förmågan att överbrygga olikheter mellan dem genom att hjälpa dem att förstå varandras skilda utgångspunkter, erfarenheter och sammanhang. Samtidigt förutsätter detta ett visst mått av förfrämligande: brobyggaren måste kunna ställa sig utanför eller vara utanför på något sätt. Denna ambivalenta position inom den etablerade organisationen, och även till viss del i relation till förortsrörelsen, är gemensam för de aktuella brobyggarna i denna text.

Det är lätt att som Katherine Stovel och Lynette Shaw (2012) se paralleller mellan brobyggare och den klassiska Simmelska idén om främlingen. Främlingen, eller den potentiella vandraren, har en position som kännetecknas av närhet och distans. Att eventuellt vara på väg någon annanstans men ändå tillhöra skapar enligt Georg Simmel (I98I [I908]) förutsättningar för en särskild form av objektivitet eller frihet, en möjlighet att kliva utanför och ifrågasätta det som tas för självklart. Det ger ett mer övergripande perspektiv som gör det möjligt att se bortom traditioner och teser och att sätta sig in i andra perspektiv. För Ronald S. Burt (2004) inbegriper verkande i gränssnittet en särskild förmåga att komma på innovativa idéer. Det övergripande argumentet är att "åsikter och beteenden är mer homogena inom grupper än mellan grupper. Människor som har kontakter med flera olika grupper är vana vid alter- 
nativa sätt att tänka och agera, vilket ger dem fler förslag att välja mellan och sammanfoga. Nya idéer föds ur sortering och syntes av strukturella hål mellan grupper" (Burt 2004, s. 349-350, min översättning). Brobyggare har alltså förmågan att fylla de strukturella hål, med andra ord bristen på informationsflöden, som uppstår mellan isolerade eller segregerade aktörer eller organisationer. Detta innebär att brobyggarnas position öppnar för kritiskt och kreativt tänkande. De har ett försprång genom sitt överskridande nätverk när det gäller att överföra kunskap från en kontext till en annan, sammanfoga olika delar kunskap mellan grupper eller i förlängningen skapa en övergripande syntes, i detta fall mellan olika organisationers analyser och former.

Men som Simmel redan i början på 1900-talet underströk uppfattas brobyggarens position som ett hot av de som inte är lika "fria". Att agera brobyggare är en balansgång som innebär både personliga och politiska risker (Rose 2000). Som medlem av en grupp har man vanligtvis de andra medlemmarnas tillit, men när man börjar utmana regler och normer i den egna organisationen blir man ofta obekväm. Det är en prekär uppgift att behålla förtroendet i den egna organisationen och inte betraktats som illojal, samtidigt som man utmanar formella och informella regler och grundprinciper. "Att skapa relationer med 'främlingar' och ta deras idéer på allvar utgör ett hot mot de existerande normerna i gruppen, vilket automatiskt leder till att ordningen ifrågasätts” (Rose 2000, s. I8I, min översättning). I extrema fall riskerar brobyggaren att isoleras eller uteslutas. Det större projektet att ena och arbeta för rättvisa i den urbana periferin, samtidigt som man försöker överbrygga distansen mellan förortsrörelsen och de etablerade civilsamhällesorganisationerna, skulle då kunna gå om intet och i förlängningen leda till ökad misstro och konflikt mellan de olika parterna.

\section{Från perifera uttolkare till brobyggare}

\section{Missionen som förenande kraft}

De som identifierats som brobyggare utgör en blandad skara när det gäller deras bakgrund. Vad som emellertid förenar dem är att alla drivs av vad som kan liknas vid en mission. 
Även om det är mycket som jag inte har egna upplevelser av, jag är mycket äldre, jag växte upp i en annan tid, jag har jag det liksom i min core. En känsla av att bo i ett område som inte räknas, där man tror att man inte kan bli något eller vara värd något. Hade det funnits en förortsorganisering när jag var ung, vad det hade räddat min lilla själ. Men det fanns inte på samma sätt utan man var bara tvungen att ta sig därifrån och skrika om det. (IPI)

I många fall kommer missionen före identifikation, tillhörighet och som vi kommer att se - ibland även lojalitet till den egna organisationen. Det som sammanbinder brobyggarna är ambitionen att dra igång en diskussion om den ojämlika samhällsutvecklingen och dess effekter för den urbana periferin samt att bidra till att skapa förutsättningar för en social mobilisering i marginaliserade förortsområden. Eller som en brobyggare med lång erfarenhet från en traditionell folkrörelseorganisation formulerar det:

Reglerna har ändrats och förhållanden har ändrats. Behoven, inte minst, har ändrats, och där skiljer sig naturligtvis förortsområdena våldsamt åt i sin totala brist på välfärdsområdet. (IP2)

Som följande citat illustrerar har det etablerade civilsamhällets särskilda former av tröghet eller ovilja inte lyckats möta den samtida samhällsutvecklingen mot ett mer ojämlikt samhälle där erfarenheter av rasifiering, klass och rum ofta är sammankopplade. För att samhället och dess organisationer ska behålla sin framtida relevans är det av avgörande betydelse att man lyckas påverka det etablerade civilsamhället att anta denna utmaning, och då särskilt genom sina egna organisationer.

Man missar så mycket genom att vara exkluderande genom formalia. Det är makt, och det används för att trycka ner människor. Och då kan man ju sitta och dö, varsågod och dö då alla organisationer. Men det är synd, det finns erfarenheter, det finns de som fattar och det finns en fet grundidé. Det finns resurser som borde ligga på andra platser. (IPI)

Jag tycker nog att vi är särskilt tröga. Jag började ju här 1984, då var jag 35 år och då var alla andra förtroendevalda 35 år, alla anställda var 35 år. Vi var ju som ungdomar allihop, så kände vi oss åtminstone. Men nu är det samma personal och samma förtroendevalda. $\left(\mathrm{IP}_{3}\right)$ 
Den mission som brobyggarna delar relaterar de till betydelsen av att ha verkat lokalt med dessa frågor. Även om de i dag arbetar på strategisk nivå inom etablerade organisationer har de alla erfarenhet av ett ideellt eller professionellt arbete på gräsrotsnivå i marginaliserade bostadsområden, och vissa har även personliga erfarenheter av att bo och växa upp där. De menar att detta har gett dem oumbärliga kunskaper som inte går att få på annat sätt. Den person som citeras nedan anser exempelvis att den resa mot det arbete hen i dag bedriver inom en etablerad organisation bygger på erfarenheter av att tidigare ha gjort "alla fel" man kan göra genom att försöka servera färdiga lösningar i projektform utan lokal förankring.

Även om jag inte hade ett så kolonialt mindset har jag gjort den här koloniala resan. Jag skulle göra ett projekt om makt och jag jobbade mycket utifrån den svarta medborgarrättsrörelsen i USA och Steve Biko. [...] Det var jätteintressant och Megafonen var inblandade. Vi var fem anställda och skulle jobba med ungdomsengagemang och försöka lotsa in unga i någon form av organisering. Men i efterhand är jag väldigt kritisk, även om det gick bra. Vi lyckades nå många ungdomar, men i dag hade jag gjort det annorlunda. Jag gjorde det klassiska misstaget att komma ut med ett färdigt recept för hur projektet skulle vara, när målet borde ha varit: grabbar, tjejer, vad vill ni göra? [...] Det var en jättestark erfarenhet att vara på lokal nivå, tidigare hade jag varit på nationell nivå och pratat om det lokala. (IP4)

Brobyggarna menar att inom det lokala gräsrotsarbetet är det viktigaste att skapa förtroende, och det kan man bara göra genom att vara på plats och vara ödmjuk för hur människor i marginaliserade bostadsområden själva definierar sina problem och möjligheter.

Mycket har handlat om tillit, det är särskilda personer med en viss erfarenhet som fått respekt. Det handlar inte så mycket om bakgrund, snarare om att man varit på plats. Inte ställt krav till exempel på att man ska bli en del av [namnet på en organisation]. [...] De andra organisationerna finns ju inte där. Det har handlat om att hitta personliga strategier, men det är inte så svårt när man är där. (IP5)

Med andra ord delar de brobyggare som står i fokus för denna text en mission som bygger på närvaro $\mathrm{i}$ - och i vissa fall personliga erfarenheter av - bostadsområdena. Det innebär att de måste hantera en dubbel 
lojalitet till organisationen och missionen. Brobyggarnas reflektioner kring denna problematik uttrycktes bland annat så här:

Jag är väl en otrogen människa. Haha. Eller jag är trogen uppdraget. [...] När det gäller civilsamhällesorganisationerna vilar ju alla på samma grund, det är ju någon sorts medborgarperspektiv. Sen att det här är nykterhetsförbundet eller det här är arbetarrörelsen. Jag tror faktiskt att jag skulle kunna jobba på vilken organisation som helst. (IP5)

För andra brobyggare var missionen och organisationen mer tydligt sammankopplade, vilket hängde samman med att de bedrivit missionen inom ramen för en organisation under större delen av sin professionella karriär. I dessa fall diskuterades den egna hemorganisationen i form av ett vi, och hemorganisationens utveckling betonades som särskilt betydelsefull:

Att få in deras röst i organisationen är alltså helt avgörande för oss och att det är förankrat från stämman till fullmäktige. ( $\left.\mathrm{IP}_{3}\right)$

De brobyggare som i detta material har en mer spretig organisatorisk och professionell tillhörighet är yngre och har arbetat på olika typer av positioner, i olika organisationer och branscher. De framhåller ett behov av att röra på sig, beroende på var de kan ha mest att vinna både personligen och utifrån missionen. Till exempel att det finns andra personer $i$ en organisation som delar samma mission, och att det finns ett visst utrymme att driva de frågor man brinner för.

Sammanfattningsvis är det som förenar denna blandade skara av brobyggare en gemensam mission eller en övertygelse om att lyfta fram den urbana periferins villkor och arbeta för en lokalt förankrad mobilisering. Denna analys grundar de i erfarenheter av att ha arbetat lokalt i marginaliserade bostadsområden; vissa av dem har också personliga erfarenheter av att växa upp i motsvarande miljöer under 1970- och 80-talen. Det som till viss del skiljer dem åt är identifikationen med och lojaliteten till den egna hemorganisationen: vissa ser förändring av den egna organisationen som central medan andra anser att den etablerade civilsamhällesorganisation de för tillfället arbetar på främst är ett medel att nå det mer övergripande målet. 


\section{I mötet med förortsrörelsen}

De personer som i denna studie identifieras som brobyggare var alla med när olika organisationer inom ramen för förortsrörelsen i slutet på oo-talet och början på ıo-talet tog sina första steg. Som tidigare nämnts har alla lång erfarenhet av att arbeta och verka i marginaliserade bostadsområden, och genom detta arbete har de försökt lyfta frågan om den urbana periferin i den egna organisation och skapa utrymme eller möjligheter för en förändringsinriktad social mobilisering för och av unga lokalt. Emellertid är det först i mötet med den framväxande förortsrörelsen som de intar rollen av brobyggare. Positionen förutsätter att det finns minst två aktörer att knyta samman eller medla mellan, och genom förortsrörelsen uppstår denna andra aktör (Stovel \& Shaw 20I2).

Detta betyder inte att det inte redan finns eller har funnits engagemang, aktivism eller ett rikt lokalt föreningsliv i dessa orter (se exempelvis Kings 20II). Genom sitt tidigare arbete har brobyggarna försökt skapa förutsättningar och möjligheter för att aktörer som förortsrörelsen ska kunna uppstå och utvecklas. Men det var först med förortsrörelsens organisationer som det i alla fall under en period uppstod en potentiell motpart som liksom den traditionella folkrörelsemodellen sammanfogade lokal förankring med ett utåtriktat förändringsarbete. Under denna period kunde organisationer från olika städer mötas utifrån gemensamma erfarenheter med krav på rättvisa. Det är mot denna bakgrund som förortsrörelsen sågs som något nytt som bidragit till att aktualisera centrala problem:

Men det finns något med att frågorna inte går att undgå längre och det är ju något helt nytt. Vi står inför något slags paradigmskifte. Om du nu står och pratar OM förorten så har du helt plötsligt 20 som pratar utifrån orten. Dom här rösterna börjar bli starkare i debatten. (IPI)

Detta betyder inte att relationen till förortsrörelsen alltid varit konfliktfri eller att man varit överens i alla frågor och arbetssätt eller med olika personer, grupperingar och organisationer. Vidare framhåller vissa att mötet med förortsrörelsen ibland också skapade jobbiga men ofta nödvändiga ifrågasättanden av den egna personen, till exempel gällande deras professionella roll, ålder, kön, nuvarande klassposition och erfarenheter av att rasifieras: 
Vad vinner du på att göra det här för oss? Som att det inte skulle kunna finnas att frågan skulle kunna vara precis lika viktig även för mig. Alltså som att jag är en organisation, det är jag inte. Jag är en person med ett gäng erfarenheter och jag tycker både det här på politisk nivå, men jag tycker också det är viktigt för mig personligen. Men det får man deala med själv, tänker jag. (IPI)

Sen kom den här rasifieringsdebatten för några år sedan. Jag och [namn på en person] och [namn på en person] är ju vita, och vi tog det olika allihop. [Namn på en person] är också kvinna och många av dom här är ju män, och många av dom är ju icke-vita. Dom stöttade varandra djupare och jag kände mig ibland lite utanför när man ser på Facebook att dom har haft en middag. Men jag har också blivit vuxen. [...] Jag vet ju att jag gör ju ett bra jobb. (IP5)

Dessa spänningar är inte heller begränsade till relationen mellan individuella brobyggare och rörelsens aktivister utan kan betraktas som en del av ett identitetsskapande i en framväxande rörelse (León Rosales \& Ålund 20I7). Samtidigt som spänningarna både kunde skava och tvinga fram självreflektion var den gemensamma grundanalysen att det finns ett behov av en rörelse nu och i framtiden.

När det gäller brobyggarnas konkreta stöd till förortsrörelsens organisationer är de alla noga med att understryka sin egen begränsade betydelse:

Det är väldigt viktigt att komma ihåg att dom hade blivit Megafonen både utan mig och [namn på en person]. Det märktes ju på vilka ungdomar det var, det var inte genomsnittet $i$ alla fall, om man ser till både intresset för studier och politik och samhällsintresse. [...] I mitt ideella arbete så hade jag en mentor som var i 70-årsåldern och som gjorde att jag träffade gamla Palestinaresenärer som var 60 plus. Och jag märkte, jag träffar I7-åringar i Husby som har mer gemensamt med mina svenska gubbar i 70-årsåldern. Det är jag som är den misslyckade parentesen. [Namn på en aktivist], det var han som introducerade för mig Paulo Freire, och så kom jag på att en gammal gubbe i Borlänge hade pratat om Paulo Freire och jag tänkte, vänta nu, det är något jag har missat här. (IP6)

Brobyggarna framhåller också att deras roll främst har varit att fungera som stöd, organisera enstaka samarrangemang eller utgöra samtalspartner och vid behov bistå med mindre resurser för exempelvis en resa eller med kontakter för att få tillgång till en lokal. I det fall ett mer omfattande och längre samarbete genomförts med en organisation inom förortsrörelsen framhåller den aktuella brobyggaren att de som etablerad organisation varit noga med att stå i bakgrunden och tona ner sin roll: 
Vi syns inte där med vår logga. Jag har aldrig stått på scenen och sagt hej och välkommen till [namn på ett evenemang]. Det är alltid ungdomarna, jag finns inte ens med, jag står bara där i bakgrunden, men det är klart att jag är med och man driver ju så att säga frågor här och där. (IP4)

Den etablerade organisationen stod för finansiering, men i övrigt har det med andra ord varit upp till de unga aktivisterna att organisera, administrera och annonsera - allt i eget namn. Under Io-talets början gick också brobyggare från olika organisationer samman för att skapa möjligheter för att rörelsens organisationer från olika städer skulle kunna mötas och diskutera gemensamma frågor. De verkar dock vara rörande överens om att frågorna och kampen måste ägas av de unga själva, eller som en av dem i uttrycker det:

Mitt grundantagande var att det behövs både gamla och nya folkrörelser och dom nya måste ha en egen identitet, dom måste veta vilka dom är och dom måste formulera sin egen agenda. (IP2)

Sammanfattningsvis synliggörs här hur individer med en gemensam mission inom de etablerade civilsamhällesorganisationerna intar positionen av brobyggare i mötet med den framväxande förortsrörelsen. De verkar med andra ord i gränslandet mellan den nya rörelsen och den etablerade hemorganisationen, två olika typer av aktörer som i stor utsträckning verkat isolerade från varandra (jfr Stovel \& Shaw 20I2). Samtidigt har de personer som identifieras som brobyggare i denna text tidigare verkat som uttolkare och bland annat genom lokalt arbete försökt uppmuntra eller ge utrymme för utvecklandet av rättviseinriktade organisationer från marginaliserade områden. Brobyggarna besitter genom detta arbete lokal kunskap, erfarenhet och ett visst förtroende hos de unga aktivisterna. Deras organisatoriska erfarenheter, lärdomar och i viss mån ekonomiska resurser samt det faktum att de representerar en etablerad civilsamhällesorganisation har använts som resurser i utvecklandet av en förortsrörelse. Primärt har dock brobyggarnas fortsatta arbete handlat om att använda den nya rörelsens analyser, verksamheter och legitimitet för att förändra sina egna traditionella civilsamhällesorganisationer och sammanhang i en riktning de anser vara eftersträvansvärd och nödvändig. 


\section{Förnyelse av den egna organisationen}

Den analys som brobyggarna gör och den mission de beskriver som drivkraften i sitt arbete är inte frikopplad från den egna organisationen. Oavsett skillnader när det gäller identifikation och lojalitet med hemorganisationen grundar och legitimerar brobyggarna sin mission utifrån den egna organisationens ursprungliga värdegrund (när det gäller folkrörelserna) eller i linje med ett pågående utvecklingsarbete (den internationella hjälporganisationen). Så här resonerar en brobyggare från en traditionell folkrörelseorganisation:

Jag menar att det faktiskt är organisationen jag arbetar för som många gånger har glömt bort sin egen grundidé. Grundidén är kraftfull och utgår ifrån egenmakt i det egna området och en gemensam mötesplats som drivs av de som bor där. Inte utifrån, inte uppifrån. Den idén är betydligt mer grundad och genomtänkt bland de organiserade unga i orten vi träffar, än i organisationen i övrigt. (IPI)

Här finns också en övergripande kritik mot det som tidigare har beskrivits som rådande professionalisering av och rationaliseringsprocesser $\mathrm{i}$ civilsamhället (Wijkström 20I2; Papakostas 2OII):

Det finns en institutionalisering av civilsamhället, men det är för mig en negativ sak. Att man har kommit längre ifrån det egentliga kärnuppdraget. Att man kommer längre ifrån varför man bildade den här organisationen, längre ifrån idén och det idéburna. (IP5)

Brobyggarna är med andra ord kritiska, både mot den egna organisationen och det etablerade civilsamhället som helhet när det kommer till ökad professionalisering och distans mellan ledare och ledda. Att den egna organisationen och det etablerade civilsamhället i stort inte är förankrade på platser med stora behov framhåller de som en avvikelse från såväl egna som rörelsens och organisationens ideal. I denna anda legitimeras den mission de driver av både historien och framtiden. Det blir också ett sätt att motarbeta samtida processer i civilsamhället som de menar driver på en utveckling som underminerar vad de anser vara viktiga delar av civilsamhällets roll. Med andra ord ses alltså inte missionen per definition som en förändring av organisationen utan snarare som en återgång till dess verkliga eller ursprungliga tanke och tradition - om än i ny tappning. 
Med denna analys intar brobyggarna en specifik position i hemorganisationen. De beskriver den själva som "en udda fågel", "lonely wolf" eller som "en spion i källaren". IP2 fortsätter att beskriva sin ambivalens till att arbeta strategiskt på nationell nivå så här:

IP2: Det är säkert något fel med mig. Det kan handlar om sådana petitesser, jag orkar inte med att koppla av här på arbetet och prata om gardiner liksom.

LISA: Prata småsnack liksom?

IP2: Jag kan också småsnacka men det är på något sätt som att kontrasten blir så stor, när man som jag hela tiden är ute på fältet. Det är skarpa situationer och så kommer jag liksom hem till moderskeppet och där har det inte hänt någonting. Teet är fortfarande varm i kopparna.

Detta citat illustrerar, förutom frustration, en särskild roll som kan jämföras med Simmels idé om främlingen (198I [1908]): att vara en del av en organisation men ändå inte riktigt tillhöra den. För Simmel innebär detta att det finns utrymme för en viss form av tankemässig frihet som gör att man ser bortom det föregivandetagna. Genom möjligheten att röra sig mellan olika aktörer, i detta fall den etablerade hemorganisationen och förortsrörelsen, har brobyggare satt sig in i olika perspektiv och erfarenheter och sammanfogat sina slutsastser i en övergripande analys. Med blicken vänd mot det traditionella civilsamhället och dess organisationer handlar det om att styra det etablerade civilsamhället i en nygammal riktning som går ut på att överbrygga vad Burt (2004) kallar strukturella hål och i detta fall skapa en permanent och legitim länk mellan det etablerade civilsamhället och den urbana periferin.

Samtidigt innebär positionen som brobyggare och det främlingskap denna position till viss del förutsätter risker av olika slag (Rose 2000). För de brobyggare som behandlas här blev detta extra tydligt under år 20I3, då bland annat Megafonen omdebatterades och kritiserades starkt i medierna. I anslutning till de våldsamheter som startade i Husby under försommaren 2013 hade Megafonen en presskonferens som direktsändes över nätet på Sveriges Television. Med presskonferensen, som gjorde Megafonen rikskänd, och i efterföljande intensiva medierapportering försökte de unga aktivisterna belysa de strukturella förklaringarna till våldet i deras hemort samtidigt som de valde att inte aktivt ta avstånd och fördöma de unga som deltog i våldsamheterna. Detta ledde till en hätsk 
offentlig debatt där Megafonen av vissa målades ut som våldsmakare och uppviglare. Debatten påverkade Megafonen som organisation och rörelsen i stort (Schierup m.fl. 20I4) men fick under en period stora konsekvenser även för brobyggarna, både privat och professionellt.

Det var ju fruktansvärt jobbigt. När upploppen skedde, det medförde ju massa konsekvenser. Alltså den här organisationen, det var krig i organisationen. ( $\left.\mathrm{IP}_{3}\right)$

Det priset jag betalade, vilket var värt det alla dagar, var att jag satt i kylskåpet ett par år efter [namn på ett projekt]. [...] Jag tror att man uppfattade mig som kritisk mot organisationen. Man köpte ju hela den mediala bilden av Megafonen. (IP6)

Efter den våldsamma sommaren och de etablerade civilsamhällesorganisationernas olika former av "konflikthantering" har arbetet med dessa frågor fortsatt att utvecklas i de tre etablerade organisationer som ingår i denna studie. Ur ett större perspektiv bidrog förortsrörelsen till att synliggöra frågor om mobilisering i marginaliserade bostadsområden i samhällsdebatten (Schierup m.fl. 20I4). För de personer som här identifieras som brobyggare medförde förortsrörelsens större genomslag i den allmänna diskussionen att de frågor och de personer de själva arbetat med eller mött i olika sammanhang fick mer uppmärksamhet både från den egna hemorganisationen och allmänheten i stort. Därmed framhåller brobyggarna, oavsett organisatorisk tillhörighet, att deras arbete har fått ett större genomslag i organisation. I två av organisationerna är nu det lokala utvecklingsarbetet i marginaliserade bostadsområden prioriterat, och det är även en del av den reguljära verksamheten på strategisk nivå. Från enskilda individer har mindre grupper formats och vissa projektanställningar har ersatts av tillsvidareanställningar. Vidare har de två organisationerna tagit fram särskilda program för hur man inom organisationen ska arbeta med dessa frågor och kunna säkra långsiktighet och lokalt ägandeskap:

Vi är på väg till någonting större. Det är ett långsiktigt, teoretiskt och praktiskt arbete. (IP4)

I den tredje organisationen, som i jämförelse med de andra organisationerna har en stor medlemsbas och därmed en mer komplicerad organi- 
sationsstruktur, antog förbundsstämman 2016 ett nytt framtidsprogram som bland annat inbegriper dessa frågor. Utan att överdriva de enskilda personernas betydelse för övergripande förändringsprocesser i stora och många gånger tröga organisationer är det ändå möjligt att konstatera att de bidragit till att samtliga tre organisationer har tagit steg mot att försöka skapa en mer stabil organisation för dessa frågor.

Vi har fått till ett framtidsprogram och jag är oerhört mer optimistisk i dag att [namn på organisation] ska kunna ställa om. (IP6)

Även om de har kommit olika långt och har olika lösningar i olika organisationer har det också utvecklats en fördjupad kontakt mellan brobyggare i de olika etablerade organisationerna. Detta band mellan brobyggare från olika organisationer har fungerat stödjande för dem i organisationernas förändringsprocesser. Även om vissa redan kände varandra sedan tidigare har dialogen och samarbetet kommit att fördjupas över tid.

Det har varit en kombination av att behöva snacka skit om sin egen organisation, eller berätta om något problem man har inom sig. Men sen så har vi också försökt göra några konkreta saker tillsammans, till exempel den här arbetskonferensen. (IPI)

Inför framtiden är det särskilt två internt relaterade frågor som förenar brobyggare från olika organisationer. Den ena handlar om behovet av att anställa fler samt att strategiskt rekrytera personer med lokalkännedom och/eller med bakgrund i organisationer knutna till förortsrörelsen.

IP5: Vi har fått pengar från [namn på en myndighet]. Nu ska vi sätta oss nästa vecka och både jag och [namn på en person] menar att vi måste driva att vi ska bli fler om vi menar allvar.

LISA: Du menar anställa fler?

IP5: Ja, och vi ska tänka representativt för att ha någon trovärdighet.

Flera olika exempel på rekryteringar från förortsrörelsen lyfts fram, och det det poängteras att de inte alltid fungerar friktionsfritt. Samtidigt menar man att förfarandet är nödvändigt om det etablerade civilsamhället ska kunna vara relevant. Den andra frågan som sysselsätter brobyggarna är att försöka skapa förutsättningar för ett utvecklingsarbete som 
inte är personbundet. Genom bland annat strategiska nyrekryteringar försöker man institutionalisera de frågor och arbetssätt man utvecklat och göra dem mindre personbundna.

Sammanfattningsvis understryks här att brobyggarnas verkliga kamp utspelar sig på hemmaplan, i den egna organisationen. För deras specifika, om än prekära, position har framväxten av förortsrörelsen varit betydelsefull i och med att den förankrat och legitimerat deras arbete med att förändra förutsättningarna för den urbana periferin, och då särskilt det etablerade civilsamhällets roll i sammanhanget. Vidare har utvecklingen också lett till ett förstärkt nätverk mellan brobyggare inom olika etablerade civilsamhällesorganisationer.

\section{Sammanfattande diskussion}

Denna studie visar hur personer inom etablerade civilsamhällesorganisationer kommit att fungera som brobyggare i och med framväxten av förortsrörelsen. Dessa personer delar erfarenheten av att ha arbetat på gräsrotsnivå och har utvecklat ett särskilt förhållningssätt; de har även en gemensam mission. Rollen och positionen som brobyggare har använts för att stödja förortsrörelsens uppstart genom att frigöra kapital, stödja och skydda. Men för de enskilda personerna som har agerat som brobyggare är det också tydligt att kampen i förlängningen handlar om att förändra den egna organisationen. Enligt brobyggarna har denna kamp efter både framgångar och motgångar inneburit en viss förändring av de etablerade organisationer som de arbetar för. Inom dessa har ett internt förändringsarbete påbörjats som både inbegriper marginaliserade områden som ett nygammalt verksamhetsområde och har öppnat för en diskussion som handlar om den egna organisationens utveckling och värdegrund inför framtiden. Det ska dock noteras att detta sammanfaller med en mer allmän diskussion om det etablerade civilsamhällets stagnation och behov av förnyelse. För att möta dessa utmaningar pågår i dag en mobilisering hos många organisationer inom det etablerade civilsamhället. Det är exempelvis vanligt att marginaliserade områden ses som intressanta och viktiga att etablera sig i för att nå nya potentiella medlemmar och utveckla nya verksamheter. Det som skiljer de traditionella organisationerna åt är 
emellertid deras grad av legitimitet när de arbetar i dessa områden, en legitimitet som ofta sammanfaller med graden av lokal förankring.

Samtidigt är det värt att diskutera behovet av brobyggare som sådana, då det synliggör det avstånd som finns mellan det etablerade civilsamhället och den nya rörelsen. Som tidigare studier visat har det etablerade civilsamhället i Sverige, och då även de äldre folkrörelserna, haft stora svårigheter att möta både de lokala behov och de protester som finns i stadens marginaliserade områden (Kings 20II). Omförhandlingen av civilsamhället och den traditionella folkrörelsemodellen, en växande ojämlikhet och en identifiering av nya och gamla behov som inte hittat sin form eller som man förbisett i det etablerade civilsamhället, är en del av bakgrunden till den distans och också misstro som existerar mellan förortsrörelsen och det etablerade civilsamhället. Genom att människor och områden antingen har åsidosatts eller blivit föremål för utifrån komna projekt utan lokal förankring av etablerade organisationer har det skapats en reva inom det svenska civilsamhällets geografi. Men frågan är om detta är ett fenomen som är begränsat till den urbana periferin eller om det är en illustration av en samtida utveckling mot ett alltmer differentierat civilsamhälle. Eller för att använda analogin om den svenska folkrörelsemarinaden: om just denna marinad är att betrakta som utgående och inget nytt marinadrecept står att finna kan det organisatoriska landskapet bli mer öppet och potentiellt mer varierat eller differentierat utifrån både plats, grupp, form och innehåll. Något som talar för detta är uppkomsten av olika och motstridiga tendenser, exempelvis uppsvinget för det tidigare i Sverige så föraktade begreppet välgörenhet, även om det nu också finns omstöpt i fräsigare förpackningar som volontärarbete (Wijkström 20II). Samtidigt har grupper från den autonoma vänstern blivit mer framträdande inom exempelvis boendefrågor och bedriver i dag bland annat en kamp mot så kallade renovräkningar gentemot Hyresgästföreningen och bostadsbolagen (Richard \& Polanska 20I7).

En annan tes som kan sorteras in under detta argument är att folkrörelsernas rationalisering, som bland annat innebär att det aktiva medlemskapets demokratiska fostran fått ge vika för andra former av deltagande, har skapat ett demokratiskt tomrum som enligt Apostolis Papakostas (2012) håller på att intas av "ocivila" krafter från den extrema 
högern. Men att den extrema högern slåss om detta "tomrum" innebär inte att det inte finns andra utmanare. Det visar bland annat den mobilisering och etablering av nya nätverk, exempelvis Refugees Welcome, som uppstod i samband med den stora flyktingvågen till Sverige hösten 2015 (Turunen \& Weinryb 20I7), eller varför inte förortsrörelsens kamp för rättvisa. Framväxten av ett samtida civilsamhälle som kännetecknas av uppdelning, distans och motstridighet skapar utrymme för och behov av personer och positioner som kan länka samman olika organisationer. Mot denna bakgrund kan ett växande utrymme för brobyggare ses som ett sätt att (re)vitalisera en förstelnad folkrörelsetradition, men brobyggarna innehar samtidigt en maktposition där någon eller några har möjlighet att skapa förändring för många. Beroende på vilka framtidens brobyggare är och i vilken riktning vi vill att samhället ska utvecklas finns det med andra ord också allsköns faror förknippade med att denna position făr allt större utbredning inom civilsamhället.

\section{Referenser}

Ahrne, Göran \& Papakostas, Apostolis (2014) Organisationer, sambälle och globalisering. Tröghetens mekanismer och förnyelsens förutsättningar. Lund: Studentlitteratur.

Amnå, Erik (2007) "Associational life, youth, and political capital formation in Sweden. Historical legacies and contemporary trends", i Trägårdh, Lars (red.) State and civil society in northern Europe. The Swedish model reconsidered. New York: Berghahn Books.

Burt, Ronald S. (2004) "Structural holes and good ideas", American journal of Sociology, IIO, 2, s. 349-399. DOI: https://doi.org/I0.1086/421787

Heckscher, Gunnar (1946) Staten och organisationerna. Stockholm: Kooperativa förbundets bokförlag.

Kings, Lisa (20II) Till det lokalas forrsvar. Civilsambället i den urbana periferin. Lund: Arkiv. Kings, Lisa (20I4) "Förortens organisationer och kampen för förnyelse", i Fokus I4. Om ungas fritid och organisering. Stockholm: Myndigheten för ungdoms- och civilsamhällesstudier.

Kings, Lisa, Ålund, Aleksandra \& Tahvilzadeh, Nazem (2016) "Contesting urban management regimes. The rise of urban justice movements in Sweden", i Agustín García, Óscar \& Jørgensen, Martin Bak (red.) Solidarity without borders. Gramscian perspectives on migration and civil society alliances. London: Pluto Press.

León Rosales, René \& Ålund, Aleksandra (2017) "Renaissance from the margins. Urban youth activism in Sweden", i Ålund, Aleksandra, Schierup, Carl-Ulrik \& Neergaard, 
Anders (red.) Reimagineering the nation. Essays on twenty-first-century Sweden. Frankfurt am Main: Peter Lang.

León Rosales, René \& Ålund, Aleksandra (20I8 [i detta nummer]) "Aktivism som platskamp. Självpositionering och medborgarskapande inom den svenska förortsrörelsen", i Platskamp, specialnummer av Arkiv. Tidskrift för sambällsanalys, nr 9, s. 53-76. DOI: https://doi.org/I0.13068/2000-6217.9.2

Lindqvist, Johan (20I5) "The anthropology of brokers and brokerage", i Wright, James D. (red.) International encyclopedia of social and behavioral science. Amsterdam: Elsevier.

Lundström, Tommy \& Wijkström, Filip (1997) The nonprofit sector in Sweden. Manchester: Manchester University Press.

Mayer, Margit, Thörn, Catharina \& Thörn, Håkan (red.) (20I6) Urban uprisings. Challenging neoliberal urbanism in Europe. London: Palgrave Macmillan.

McAdam, Doug, Tarrow, Sidney G. \& Tilly, Charles (200I) Dynamics of contention. Cambridge: Cambridge University Press.

Meyer, David S. \& Tarrow, Sidney G. (red.) (1998) The social movement society. Contentious politics for a new century. Lanham: Rowman \& Littlefield.

Nicholls, Walter J. \& Uitermark, Justus (2017) Cities and social movements. Immigrant rights activism in the US, France, and the Netherlands, 1970-2015. Chichester: Wiley Blackwell.

Olivier de Sardan, Jean-Pierre (2005) Anthropology and development. Understanding contemporary social change. London: Zed.

Olofsson, Gunnar (1995) Klass, rörelse, socialdemokrati. Essäer om arbetarrörelsens sociologi. Lund: Arkiv.

Papakostas, Apostolis (20II) "The rationalization of civil society", Current sociology, 59, I, s. 5-23.

DOI: https://doi.org/I0.II77/ooII392110385967

Papakostas, Apostolis (20I2) "De medlemslösa organisationernas tidevarv", i Wijkström, Filip (red.) Civilsambället i sambällskontraktet. En antologi om vad som står på spel. Stockholm: European Civil Society Press.

Polanska, Dominika V. (2015) "Alliance-building and brokerage in contentious politics. The case of the Polish tenants' movement", i Jacobsson, Kerstin (red.) Urban grassroots movements in Central and Eastern Europe. Farnham: Routledge.

Richard, Åse \& Polanska, Dominika V. (2017) "Renovräkt. När profiten tar din bostad", Ordfront, 3, s. 22-27.

Rothstein, Bo (1992) Den korporativa staten. Intresseorganisationer och statsförvaltning $i$ svensk politik. Stockholm: Norstedts juridik.

Rose, Fred (2000) Coalitions across the class divide. Lessons from the labor, peace, and environmental movements. Ithaca: Cornell University Press.

Schierup, Carl-Ulrik, Ålund, Aleksandra \& Kings, Lisa (2014) "Reading the Stockholm riots - a moment for social justice?", Race \& Class, 55, 3, s. I-2I. DoI: https://doi.org/I0.II77/030639681350919I

Sernhede, Ove (2014) "Youth rebellion and social mobilisation in Sweden", Soundings. A journal of politics and culture, 56, II s. 8I-9I. 
Simmel, Georg (1981 [1908]) "Främlingen”, i Simmel, Georg, Hur är samhället möjligt? — och andra essäer. Göteborg: Korpen förlag.

Stahre, Ulf (2007) Den globala staden. Stockholms nutida stadsomvandling och sociala rörelser. Stockholm: Atlas.

Stovel, Katherine \& Shaw, Lynette (20I2) "Brokerage", Annual Review of Sociology, 38, I, s. I39-I 58 .

DOI: https://doi.org/IO.II46/annurev-soc-08I309-I50054

Tarrow, Sidney G. (1994) Power in movement. Social movements, collective action and politics. Cambridge: Cambridge University Press.

Thörn, Håkan (2013) Stad i rörelse. Stadsomvandlingen och striderna om Haga och Christiania. Stockholm: Atlas akademi.

Turunen, Jakko \& Weinryb, Noomi (20I7) ”Volontärer i välfärdsstaten. Socialt arbete med transitflyktingar som politisk handling", i Linde, Stig \& Scaramuzzino, Roberto (red.) Socialt arbete i civilsamhället. Aktörer, former och funktioner. Lund: Studentlitteratur.

Urban, Susanne (2018) Integration och grannskap. Hur kan staden hålla samman? Lund: Studentlitteratur.

Vogel, Joachim m.fl. (2003) Föreningslivet i Sverige. Välfärd, socialt kapital, demokratiskola. Stockholm: Statistiska centralbyrån.

Wijkström, Filip (20II) "'Charity speak and business talk'. The on-going (re)hybridization of civil society", i Wijkström, Filip \& Zimmer, Anette (red.) Nordic civil society at a cross-roads. Transforming the popular movement tradition. Baden-Baden: Nomos.

Wijkström, Filip (20I2) "Hybrider i civilsamhället. När filantropiskan och ekonomiskan kom till byn”, i Wijkström, Filip (red.) Civilsambället i samhällskontraktet. En antologi om vad som står på spel. Stockholm: European Civil Society Press.

Wijkström, Filip, Reuter, Marta \& Emami, Abbas (red.) (20I7) Civilsambället i det transnationella rummet. Stockholm: European Civil Society Press.

\section{Inspelat material}

IPI, tjänsteperson folkrörelseorganisation I, intervju Io maj 20I7, IO7 minuter.

$\mathrm{IP} 2$, tjänsteperson folkrörelseorganisation I, intervju Io november 20I6, I39 minuter.

$\mathrm{IP}_{3}$, tjänsteperson folkrörelseorganisation 2, intervju II oktober 20I6, IOO minuter.

$\mathrm{IP}_{4}$, tjänsteperson internationell hjälporganisation I, intervju 5 maj 20I4, 89 minuter.

IP5, tjänsteperson folkrörelseorganisation I, intervju 2 november 20I6, II4 minuter.

IP6, tjänsteperson folkrörelseorganisation 2, intervju 25 oktober 20I6, IO3 minuter. 


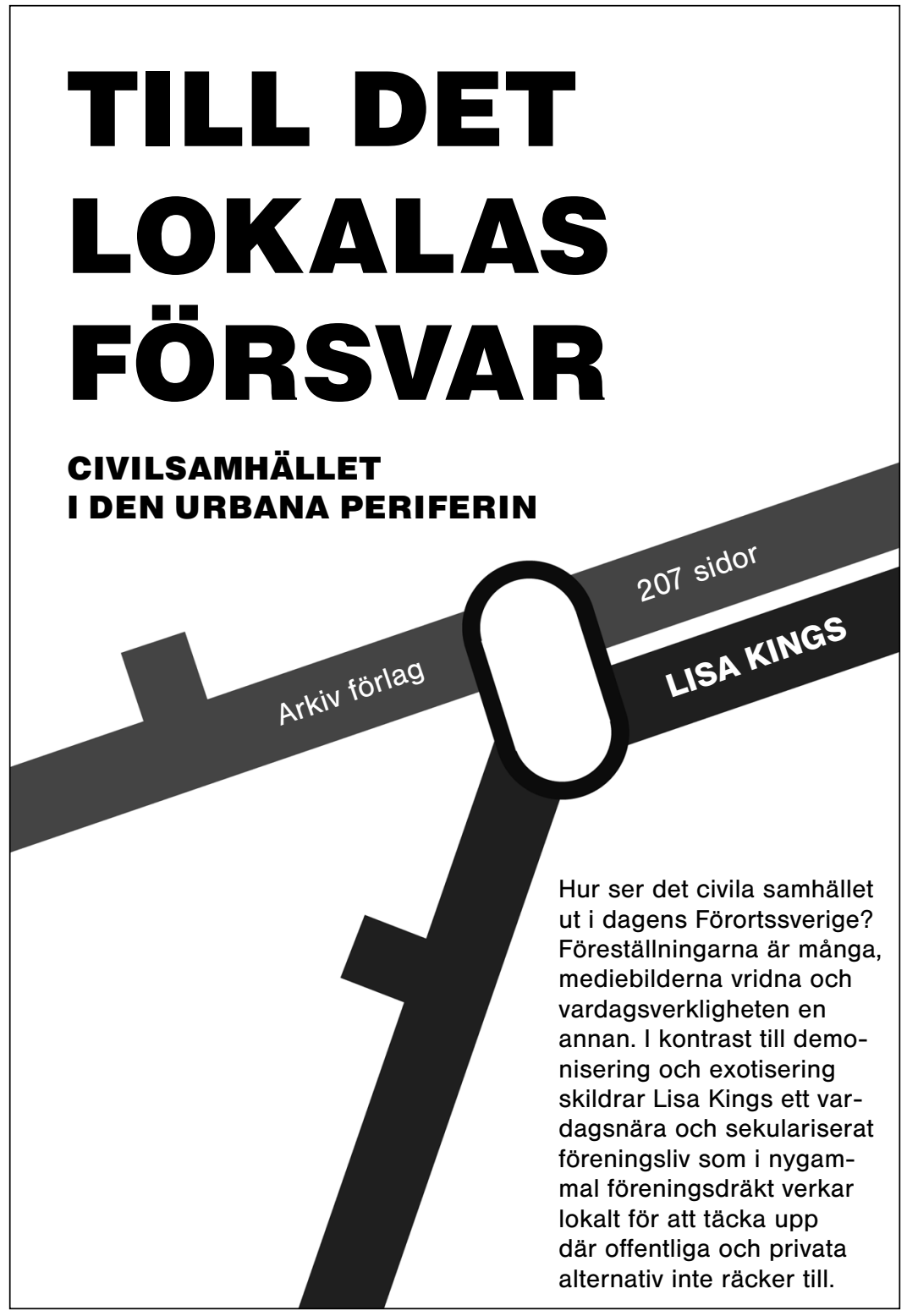

"Läs mer om boken på www.arkiv.nu« 


\section{Mats Franzén Eva Sandstedt}

Välfärdsstat och byggande

\section{Om efterkrigstidens nya stadsmönster i Sverige}

I denna klassiska studie om efterkrigstidens svenska stadsutveckling visar Mats Franzén och Eva Sandstedt på den paradoxala kontinuitet som rått i bostadsbyggandet från efterkrigsråren och över miljonprogrammets period. De visar hur de förortsområden som i efterhand fördömts för sin isolerande och gemenskapsdödande effekt byggdes utifrån samma "grannskapsideologi" som präglade redan 50-talets byggande. Ambitionen var tvärtom att bygga goda bostäder och dessutom skapa förutsättningar för demokratiskt samverkande kollektiv i "grannskapsenheter". Välfärdsstat och byggande är ett banbrytande arbete, oundgängligt för alla som är intresserade av samhällsplaneringens villkor.

Arkiv förlag, 354 sidor

\section{ARkiv}

»Läs mer om boken på www.arkiv.nu« 